\title{
Compliance to Online Retail of Electronic Nicotine Delivery Systems (ENDS) in India before and after the 2018 Ban Order of the Government of India
}

\author{
Pranay Lal*, Ragini Kapoor, Rana Jugdeep Singh
}

\begin{abstract}
Since their launch globally in 2012, electronic nicotine delivery systems (ENDS) were positioned as a harm reduction strategy and cessation device but it is yet to be proven to have clinical safety or public health benefits. Instead, recent reports suggest that the tobacco industry targeted youth and sponsored research whose evidence was used to mislead policymaking. On August 28, 2018, Ministry of Health \& Family Welfare's advisory banned the sale, purchase, and trade of ENDS. A survey was done in two waves. The first survey was done between August 10 and 252018 all websites which sold ENDS product were mapped and documented. The survey was repeated (November 30, 2018) were after the restriction to trade on ENDS was proposed by the Department of Customs. The two waves of survey found that no website, whether comprehensive e-commerce portals or dedicated ENDS marketing platforms fully complied with government orders. National and states government enforcement agencies are currently unaware of internet-based sale of ENDS. Although some states have given specific directions to stop the sale and delivery of ENDS within the state through e-commerce, there is limited monitoring and legal compliance by seller. Public health advocates need to stay vigilant and monitor the online sale and point of sale retail of ENDS to ensure strict compliance of national and state regulations.
\end{abstract}

Keywords: Electronic nicotine delivery systems (ENDS)- tobacco control, industry behaviour- public policy

Asian Pac J Cancer Prev, 22, Progress of Tobacco Control in the South-East Asia Region Suppl, 13-17

\section{Introduction}

The Oxford Living Dictionary defines electronic nicotine delivery systems (ENDS) as "a cigarette-shaped device containing a nicotine-based liquid that is vaporized and inhaled, used to simulate the experience of smoking tobacco" (Oxford English Dictionary, 2018). It works by heating a liquid to generate an aerosol, commonly called a "vapour" that the smoker inhales. ENDS are commonly marketed as electronic cigarette or e-cigarettes. The use of e-cigarette is becoming popular and is generating considerable interest among the potential consumers. The modern e-cigarette (a type of ENDS) was invented and patented by a Chinese pharmacist in 2003 and has since become popular all around the world (Hajek P et al., 2014). Most ENDS are produced by Chinese manufacturers based in Shenzhen area of Guangdong province. Complete ENDS and ENDS accessories are globally exported from China.

The global public health community and within it, the tobacco control advocates are divided on how it proposes to address the possible public health gains, imminent addiction and probable health risks posed by new technologies like ENDS. They are divided between strongly regulating ENDS, with some countries banning it trade, to those keeping its application in abeyance unless its efficacy is proven. On the other hand, countries with high prevalence of smoking have considered ENDS as a possible "reduced risk product" (a term promoted by the tobacco industry in their submission to the regulators such as the US Food \& Drug Administration) (Food and Drug Administration, 2012) and have bought the argument that since the nicotine levels are supposedly less in ENDS, their risks are also perceived to be less compared to cigarettes and therefore may be used for cessation purposes for hardcore smokers (Pisinger and Døssing, 2014). The risks of ENDS are not fully known and there are few independent clinical trials. E-cigarettes are mostly unregulated. Based on the nature of domestic legislation, countries have classified ENDS in seven categories: 1) tobacco products; 2) products imitating tobacco; 3) medicinal products; 4) pharmaceutical products; 5) consumer products; 6) poison; or 7) ENDS as a restricted cessation device. Thirty countries like Brazil, Singapore, the Seychelles, Uruguay, and Brunei have banned ENDS, while some like Australia, Denmark, Belgium, and Canada among others have imposed restrictions upon sale of certain types of ENDS and others like Japan, Hungary, 
New Zealand, Norway, and South Africa offer age restrictions (World Health Organization, 2018).

Use of ENDS is fairly new in India. The Second Global Adult Tobacco Survey for India (GATS-2) conducted in 2017 has found that only $0.02 \%$ of adults currently use it. About three percent of adults in India know about e-cigarettes, and more male tobacco users (4.1\%) and in urban areas (5.1\%) were aware of ENDS than among women $(1.9 \%)$ and those in rural areas $(1.9 \%)$. Awareness of e-cigarette is the highest among adolescents (4.0\%) and decreases with age to less than one percent in agegroup 65 years or above. There is also a high variation on knowledge about ENDS - in the capital state of Delhi, 13.3 percent of adults reported having heard of it, followed by Goa (the state with the lowest tobacco use prevalence) (TISS et al., 2018).

In August 2018, The Government of India's Ministry of Health \& Family Welfare issued an advisory for states to ban use of ENDS, and this was followed by restrictions to trade, manufacture and sell ENDS by Ministry of Finance, Department of Indirect Taxes \& Customs (Government of India et al., 2018). In effect, the trade of ENDS and other new technologies has been banned in India. This paper surveys the sale of ENDS through internet websites in India since the ban orders of the Government of India.

\section{Materials and Methods}

We reviewed popular e-commerce portals (like EBay, Paytm Mall, Shopclues, Flipkart etc.) and ENDS-specific marketing websites (various Internet websites, listed below), and assessed the products sold and if products were offered without consent of age before using or purchasing an ENDS or related product. We used MeSH (Medical Subject Headings), which is the standard thesaurus for building search terms. MeSH has been developed by the US National Library of Medicine and is used for indexing research papers on MEDLINE ${ }^{\circledR}$ PubMED ${ }^{\circledR}$ database. MeSH entry terms are part of standard protocol for keyword searching both within scientific literature and Open, General Text (OGT). We built a thesaurus of terms using papers from $\mathrm{MeSH}$ which are as follows: e-cigarettes, e cigarette, e-cig, e cig, ecigs, electronic cigarette, electronic cig, Electronic Nicotine Delivery System, vape, vapour, vaping.

For the search we used a popular crawler search engine (Google) to map all general e-commerce portals and tradespecific portals which sell ENDS. To find these portals we conducted an open search using term "e-cigarette", "vape" and "electronic cigarette" AND "online sale" AND "India". We aggregated all websites which sell tobacco online, which appeared in the first 10 pages of Google (as on 5 August 2018). We found 21 sites which sold ENDS in India, for which analysis was done. The websites were divided into two categories - websites exclusively selling ENDS and e-commerce portals which sell ENDS. Once a long list of potential e-commerce and trade-specific portals was drawn, we ranked the portals using an open access site-ranking website: www.statista.com (Statista, 2018)

Websites which exclusive sell ENDS (Statista, 2018) and India's largest e-commerce portals through which 85\% of all products are sold (these include: Flipkart, Amazon, Snapdeal, Ebay, Paytm Mall and Shopclues). In these websites, ENDS and ENDS-related product were searched for the following parameters: type of product (E-cigarette, vaper, e-hookah, others ENDS), their brand name, and flavours, ingredients (including nicotine strength) and variants in which they are available. The survey also documented claims made by brands. We recorded claims which promoted ENDS as being less harmful than conventional cigarettes. This included statements such as: they are healthier, contain no carcinogens, no tar or no secondhand smoke. Other claims that we recorded included ENDS can be used in places where smoking is prohibited; ENDS are cheaper than cigarettes in the long run; and ENDS are effective for quitting conventional smoking and or promoted as a cessation. We also monitored if these websites excluded underaged users and if websites had effective age verification methods before entry into the webpages or not before a purchase was made.

We conducted the survey between August 10 and 25 2018 and mapped all website and products sold from them, and states within India where sale orders were delivered. We repeated the survey on November 30, 2018 after the restriction to trade ENDS was proposed by the Department of Customs and to assess if new products and sale in states had changed after the Government of India's Ministry of Health \& Family Welfare's advisory of August 28, 2018 had any effect on the sale of ENDS.

\section{Results}

This survey reports the leading brands sold in India (Smok, Vaporesso, and E-leaf) are manufactured in Shenzhen, China, and are available across all portals. All brands are manufactured by Chinese producers and they offer different flavours, accessories, apparels, starter kits, coils, atomizers, and guides for beginners. After examining each websites and e-commerce portal on the parameters of brands offered, claims made, type of product sold, flavours offered and age restriction during the sale, the following results were obtained.

Ecommerce portals: All major e-commerce platforms (Flipkart, Snapdeal, Paytm Mall, Shopclues, Amazon, ebay) do not offer any age restriction upon purchase of ENDS. This potentially makes ENDS accessible to minors. These sites also sell accessories with claims to enhance the vaping experience and thereby increasing brand consciousness among existing and potential, new users. Among products, the most common accessories sold are atomisers and e-liquids for ENDS (Table: Accessories (E-liquids, Mods, Coil Heads, Atomisers, Stickers by Ecommerce portals) versus Complete ENDS products/ assembled) which accompany the assembled ENDS. Most e-commerce platforms (like Flipkart, Snapdeal, Paytm Mall, Shopclues) sell e-liquids. Some of the top selling flavours are Brain freeze, Strawberry, Double Apple, Mint, pan and chocolate and are sold across all e-commerce platforms. Major brands of ENDS and accessories offered by these websites are those of Chinese manufacturers (Joyetech, Smok, Vaporesso, Geekvape, 
eLeaf, and ShenRay).

ENDS-specific websites: Online e-commerce portals like Vape Mantra; Lovelites; Purevapors; Indivape; Getmyvape exclusively sell ENDS and demand an age-verification before providing access to their site. These websites offer e-liquids, accessories, and other paraphernalia of numerous brands. The most common brands sold through these websites are Smok and Joyetech. Most of the brands offered online are companies that are registered and manufactured in China. Some websites refrain from delivering products in states where ENDS is banned. Two websites - Dampf Company (ecigdc.com), Hash Nine (hashnine.in) do not process orders if customer is based in the states which have banned ENDS sale (Punjab, Karnataka and Maharashtra). However, some websites deliver across India despite sale restrictions.

A few websites offer tutorials on how to use and assemble vape equipment (give name of those which do). Most of these sites (12 of 21 sites surveyed) have exclusive blogs and they market their products through social media sites like Facebook, Twitter, Instagram among others. This creates several opportunities for ENDS manufacturers and marketing platforms to engage and promote ENDS to existing and new users. All websites offer discount sales on certain products. Some websites (6 of 21 sites surveyed) also offer real-time, online customer care which provide instant feedback and also solicit ENDS to potential customers. These websites offer taglines such as "Quit smoke, choose vape" (Indivape.in). Many of these websites also promote products through social media (like

Table 1. Summary of Online Retail Sale of Electronic Nicotine Delivery Systems (ENDS), August and November 2018.

\begin{tabular}{|c|c|c|c|c|c|}
\hline \multirow[t]{2}{*}{ Criteria } & \multicolumn{2}{|c|}{ Phase 1 of the survey (August 2018) } & \multicolumn{2}{|c|}{ Phase-2 (November 2018) } & \multirow[b]{2}{*}{ Remarks } \\
\hline & $\begin{array}{l}\text { E-commerce } \\
\text { portals }\end{array}$ & $\begin{array}{c}\text { Websites } \\
\text { Exclusively selling } \\
\text { ENDS }\end{array}$ & $\begin{array}{l}\text { E-commerce } \\
\text { portals }\end{array}$ & $\begin{array}{c}\text { Websites } \\
\text { Exclusively } \\
\text { selling ENDS }\end{array}$ & \\
\hline Types of ENDS products sold & $\begin{array}{c}\text { All types of } \\
\text { products and } \\
\text { accessories sold }\end{array}$ & $\begin{array}{l}\text { All types of } \\
\text { products and } \\
\text { accessories sold }\end{array}$ & $\begin{array}{l}\text { All types of } \\
\text { products and } \\
\text { accessories } \\
\text { sold }\end{array}$ & $\begin{array}{c}\text { All types of } \\
\text { products and } \\
\text { accessories sold }\end{array}$ & $\begin{array}{l}\text { In Phase-1, e- commerce portals } \\
\text { and websites sold all types of } \\
\text { ENDS products (except for } \\
\text { Amazon). In phase -2, the variety } \\
\text { of products stayed the same across. }\end{array}$ \\
\hline $\begin{array}{l}\text { Mean number of brands of } \\
\text { ENDS sold }\end{array}$ & $\begin{array}{l}4.33 \\
(0-11)\end{array}$ & $\begin{array}{l}11.33 \\
(1-31)\end{array}$ & $\begin{array}{l}20.83 \\
(0-11)\end{array}$ & $\begin{array}{l}11.33 \\
(1-31)\end{array}$ & $\begin{array}{l}\text { Flipkart made the sale of ENDS } \\
\text { "temporarily unavailable" from } \\
\text { September } 1 \text { to } 14,2018 \text {. No } \\
\text { changes were observed in websites } \\
\text { exclusively selling ENDS. }\end{array}$ \\
\hline $\begin{array}{l}\text { Mean number of ENDS } \\
\text { Flavours sold. }\end{array}$ & $\begin{array}{l}16.33 \\
(0-14)\end{array}$ & $\begin{array}{l}102.19 \\
(0-394)\end{array}$ & $\begin{array}{c}2.5 \\
(0-14)\end{array}$ & $\begin{array}{l}102.19 \\
(0-394)\end{array}$ & $\begin{array}{c}\text { No changes were observed in } \\
\text { websites exclusively selling ENDS. }\end{array}$ \\
\hline Whether ENDS or E-liquids on & No & No & No & No & - \\
\hline
\end{tabular}

Whether ENDS or E-liquids on

websites mention ingredients

No

No

(0-14)

-394)

and nicotine strength

Claims made about ENDS

(1) they are healthier, contain

no carcinogens, no tar or no

secondhand smoke.

No

Yes

No

Yes advertise sale by claiming ENDS as an "healthier options". However, websites exclusively selling ENDS promote their sales by claiming E-cigarettes to be a healthier choice.

(2) Promote ENDS as a substitute for smoking in a public place

(3) Claims if ENDS are cheaper than cigarettes.

(4) A direct claim of e-cigarettes as an effective quitting aid.

(5) An indirect claims of ENDS as an effective quitting aid

(6) Whether the website offer an explicit disclaimer that e-cigarettes are not approved as smoking cessation devices.

(7) Whether the website screen underage users
No age restriction to access ENDS. a cheaper option than cigarettes.

\footnotetext{
Webpage on age restriction which restricts access to searching or purchase of ENDS
}

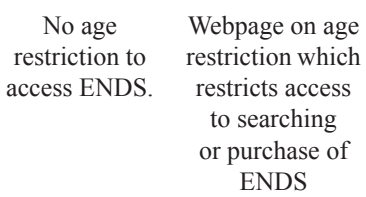

Websites exclusively selling ENDS claim the ease of use.

ENDS are promoted as a safer alternative to smoking.

There are no claims that ENDS are

ENDS-specific websites promote ENDS to be the healthier alternative to smoking tobacco cigarettes.

Customer testimonials in both which promote the product are seen in both types of websites.

None of these sites offer any disclaimer on claims.

E-commerce websites selling

ENDS do not have an age restriction to access the ENDS products. Thus, minors have access to E-cigarettes.

Websites exclusively selling ENDS screen based on age restriction. 
Facebook, Twitter and Instagram), and a few also offer tutorials and reasons to switch to vape.

Tobacco-company sponsored websites like ITC, India's largest cigarette manufacturers also market there ENDS products like Eon (https://planeteon.in/) and the website provides for a age screen on its opening page. However, Eon is marketed through an ENDS-specific website (Lovelites, 2018) including in states like Punjab where its sale is banned. ITC is the only major tobacco company in India that assembles its ENDS product in India although it sources the components from China (Mukherjee, 2014).

The repeat survey in November 2019 found only one change. The number of ENDS brands and e-liquids sold through websites has remained the same (Table 1). On August 28, 2018, the Government of India's Ministry of Health \& Family Welfare issued an advisory for states on the harms of ENDS (The Government of India, 2018) following which three e-commerce portals have stopped delivering to state of Punjab (Flipkart, Paytm Mall and Snapdeal). The state of Punjab has actively pursued strong enforcement and has warned e-commerce portals to stop delivery of ENDS and the like in the state since its first order in 2014 (Press Trust of India, 2014). No e-commerce portal has changed its marketing strategy in states or taken additional measures where ENDS are banned or has mentioned the Ministry's advisory on their website. Karnataka and Maharashtra have orders which ban online sale but all websites (including Flipkart, Paytm Mall and Snapdeal) permit delivery of ENDS within these states.

\section{Limitations}

The survey was carried out during a period of fifteen days (August 10 to 25, 2018) which coincided with a litigation in Delhi High Court that was filed by a petitioner to revoke the ban on ENDS by states, and regulate ENDS under the tobacco control legislation (The High Court of Delhi, 2018); and subsequent order of Department of Customs which bans trades of ENDS. This survey only records of the availability of ENDS before and after the ban orders of the government agencies, and does not capture information on the volume of trade of ENDS and allied products, price and or consumer information. The survey only covers the biggest online sellers based on the assessment of a single only platform (Statista, 2018) which records visits to the website but does not record online sale. It was therefore difficult to estimate sales through these websites.

In conclusion, currently no website, whether comprehensive e-commerce portals or dedicated ENDS marketing platforms fully complies with the Ministry of Health \& Family Welfare order of September 2018, and subsequent orders of the Department of Customs \& Excise, or the specific orders from the 11 states which ban sale, purchase or trade of ENDS. National and states government enforcement agencies are currently unaware of internet-based sale of ENDS. Although some states (like Punjab, Maharashtra and Karnataka) have specific directions to stop sale and delivery of ENDS and related product within the state through e-commerce, there is limited monitoring by these states and legal compliance by trading companies is limited. Public health advocates need to stay vigilant and monitor the online sale and point of sale retail of ENDS to ensure compliance of national and state regulations.

\section{Author Contribution Statement}

PL designed and conceived the study; RK and PL designed the study; RK, PL and RJS made substantial contributions to data analysis and interpretation of data; all authors contributed equally to drafting and revising the article. All authors approved the final submitted version.

\section{Acknowledgements}

The publishing cost was provided by WHO office in South-East Asia.

\section{Ethics approval}

Not commissioned since it is a review of an opensourced publically available e-commerce websites

\section{Conflicts of interest}

There are no conflicts of interest

\section{References}

Food and Drug Administration (2012). Guidance for Industry: Modified Risk Tobacco Product Applications. Draft Guidance. Washington, DC: US Government Printing Office.

Government of India, Ministry of Finance, Department of Revenue, Central Board of Indirect Taxes \& Customs (Anti-Smuggling Unit) (2018). Advisory of Electronic Nicotine Delivery Systems (ENDS), Circular NO. F. No. 394/121/2018-Cus(AS). Available at: http://www.cbic. gov.in/resources//htdocs-cbec/customs/cs-circulars/cscirculars-2018/Circular-46-2018-Customs.pdf;jsessionid= 129F8C1C11DF2DF2231D90E32F1F10E5; Government of India, New Delhi Accessed 1 September 2018.

Hajek P, Etter JF, Benowitz N, Eissenberg T, McRobbie H (2014). Electronic cigarettes: review of use, content, safety, effects on smokers and potential for harm and benefit. Addiction, 109, 1801-10.

Internet websites (2018). Available at: vapemantra.com; Lovelites.in; www.purevapors.in; www.Indivape.in; www. getmyvape.com; www.evapeshop.in; http://hashnine. in; www.vapemartindia.com; www.esutta.com; www. smartsmokeindia.com; www.madlyvape.com; www. madrasvape.com; http://ecigdc.com; www.myvapeshop. in; https://vape.co.in; www.yumvape.com; https:// indianvapegarage.in; www.litejoy.co.in; www.evolvevapors. com; www.vapeadda.com. Accessed 10-25 August 2018.

ITC Lovelites (2018). Available at: https://www.lovelites.in/itceon.html?xpage=1\&xoffset=270. Accessed 20 August 2018.

Mukherjee M (2014). ITC forays into E-cigarettes segment, will be rolled out pan-India in phases. The Economic Times (Newspaper), dated August 15, 2014. Available at: https:// economictimes.indiatimes.com/industry/cons-products/ tobacco/itc-forays-into-e-cigarettes-segment-will-berolled-out-pan-india-in-phases/articleshow/40291153. cms?from=mdr . Accessed 10 August 2018.

Pisinger C, Døssing M (2014). A systematic review of health 
effects of electronic cigarettes. Prev Med, 69, 248-60.

Press Trust of India (2014). Punjab Bans Sale of E-Cigarettes, Says E-Commerce Firms 'Can Be Booked' Gadgets 360 (Newspaper), dated November 28, 2014. Available at: https://gadgets.ndtv.com/others/news/punjab-bans-sale-of-ecigarettes-says-e-commerce-firms-can-be-booked-627030. Accessed 17 August 2018.

Statista (2018). Available at: statista.com. Accessed 10 August 2018.

Tata Institute of Social Sciences (TISS), Mumbai and Ministry of Health and Family Welfare, Government of India. (2018). Global Adult Tobacco Survey GATS 2 India 2016-17.

The Government of India and Ministry of Health \& Family Welfare advisory to states to ban ENDS and new technologies (2018). F.No- P -16012 / 19/2017 -TC, dated August 28, 2018. Available at: https://mohfw.gov.in/newshighlights/ advisory-electronic-nicotine-delivery-systems-endsincluding-e-cigarettes-heat-not . Accessed 1 September 2018.

The High Court of Delhi. Seema Sehgal (Petitioner) Vs. Union of India And Ors. (2018). W.P.(C) 10624/2017, CM No. 33757/2018; Interim order. Available at: http:// delhihighcourt.nic.in/writereaddata/upload/CauseLists/ CauseListFile_VDMSAU6NA21.PDF. Accessed 22 August 2018.

The Oxford English Dictionary (Open Access edition) (2018). Available at: https://en.oxforddictionaries.com/definition/ electronic_cigarette. Accessed 29 August 2018.

World Health Organization (2018). Progress report on regulatory and market developments on Electronic nicotine delivery systems and electronic non-nicotine delivery systems (ENDS/ENNDS). Report by the Convention Secretariat for the Conference of the Parties to the WHO Framework Convention on Tobacco Control Eighth session, Geneva, Switzerland. Available at: http://www.who.int/fctc/cop/ sessions/cop8/FCTC_COP_8_10-EN.pdf . Accessed 20 August 2018.

\section{cc) (7) (8)}

This work is licensed under a Creative Commons AttributionNon Commercial 4.0 International License. 